\title{
ECOSYSTEM SERVICES OF HOSPITAL GARDENS - BASED ON MICROCLIMATE ANALYSES OF GREEN AND BLUE GARDEN ELEMENTS
}

\author{
Vera TAKÁCSNÉ ZAJACZ1*, prof. Kinga M SZILÁGYI² \\ ${ }^{1}$ Institute of Landscape Architecture, Urban Planning and Garden Art, Hungarian University of Agriculture \\ and Life Sciences, Budapest, Hungary \\ ${ }^{2}$ Doctoral School of Landscape Architecture and Landscape Ecology, Hungarian University of Agriculture \\ and Life Sciences, Budapest, Hungary
}

*Correspondence:

Vera TAKÁCSNÉ ZAJACZ

Takacsne.Zajacz.Vera@uni-mate.hu

Received: 31 May 2021; Accepted: 11 June 2021; Published: 30 June 2021

\begin{abstract}
The increasing urbanization process of the last decades has resulted in negative impacts and changes in the quality of the urban environment, as reflected in mortality and morbidity data (Páldy, 2018). The quality of the environment, the urban climate, the increased frequency and duration of extreme weather events, ultimately threaten human well-being. To design and build liveable cities, the quality of the urban environment must be improved, and improving micro- or local climate is an important factor in this. Increasing the proportion and quality of biologically active surfaces, i.e. the ecosystem services provided by green spaces, is one of the most effective tools for urban conditioning and enhancing human well-being.

Determining the proportions of the green area, the design of vegetation, the choice of pavements and microarchitectures all determine the microclimate of an open-space. This has been confirmed by a large body of research and implemented work, but it is also important for designers to make a preliminary prediction of the impact of any intervention on the climatic conditions of the design site. These predictions will help costeffective designing to determine which intervention will result in climate change.

This research uses two specific examples to examine the effectiveness of each landscape designing tool and to show which designing tool produces what and how much climatic impact. For these studies, we used a climate modeling program (ENVI-MET), which runs simulations to infer the climate modifying effects of landscape planning tools.

In the course of the research, we have shown that the local climate of hospital gardens could be significantly influenced by favorable, environmental-friend paving, a higher green cover ratio, and a well-developed and sufficiently dense tree canopy, and various water features.
\end{abstract}

Keywords: urban microclimate, hospital gardens, ecosystem services of urban green infrastructure.

\section{Introduction}

As the world's population grows, the number and proportion of people living in cities is also increasing. Due to the increasing intensity of urban development, the city's changing radiation patterns, water balance, solar radiation, air currents and temperature have a negative impact on the urban climate, which in turn has a negative impact on our environment and well-being. The urban planning professions, such as urban designers, architects, transport engineers and landscape 
architects, are trying to respond to challenges posed by these changing conditions.

In cities, the area covered with vegetation, i.e. the vegetation and possibly the water surface, is able to compensate for negative climatic effects, improve the urban climate at least at local level, which is beneficial for the human environment, human comfort and wellbeing (Gulyás, 2009).

The aim of the research is to map and present the role of biologically active surfaces in improving urban climate, to show how green surfaces can modify the microclimate and the feeling of human comfort in an urbanized environment.
Among the land-use units that can significantly influence the urban microclimate are those with a high intensity of green spaces, such as forests, grasslands, reeds, urban green spaces, institutional areas with large green spaces, industrial and commercial areas and residential areas. The biologically active surfaces that are of great importance for the research should be supported by landscape architectural plans during the permitting process: green spaces, green space institutions, institutions with significant green space, i.e. institutional gardens (Table 1.).

Table 1. The relationship between park size and potential air temperature (Oke et al. 2017)

\begin{tabular}{|c|c|c|}
\hline The park area (ha) & Average cooling effect $\left({ }^{\circ} \mathrm{C}\right)$ & Range \\
\hline 500 & 2 & $\sim 2 \mathrm{~km}$ \\
\hline 60 & 1,5 & $\sim 1 \mathrm{~km}$ \\
\hline 0,5 & 1,5 & $\sim 150 \mathrm{~m}$ \\
\hline 0,24 & $1-2$ & $\sim 20 \mathrm{~m}$ \\
\hline
\end{tabular}

The Covid19 pandemic has highlighted the need to improve human comfort in hospitals, as patients' recovery is greatly enhanced when they are comfortable. Thus, our research has also focused on these institutional areas, and has investigated the microclimate-modifying effects of landscape architecture in hospital gardens.

Hospital gardens are in a special position in the city. Even when the first hospitals were built, great emphasis was placed on the gardens surrounding the buildings, as they were also used for healing. The hospitals built in the 19th and 20th centuries, including those in Budapest, were surrounded by large gardens. Initially these green spaces were used as healing sites, but as motorisation progressed they became parking lots, yet they have remained the same size. They have more or less avoided fragmentation and development and still form uniform surfaces today. (Takácsné Zajacz 2020) However, their position in the city has mostly changed, as the former periurban hospitals have been surrounded by the city, and now the mostly large green institutional gardens are located in the inner, green-deficient parts of the cities (Fig. 1.)

The local climate of gardens is basically determined by two specific urban meteorological processes: the formation of a cool island and the local park circulation due to the temperature difference. The vegetation, the pavement and the water surfaces are primarily responsible for the formation of the cool island. The formation of a cool island generates park circulation, which enhances the microclimatemodifying effect of the green surface, thus also having a beneficial effect on thermal sensation and human comfort (Oke et al. 2017).

In Table 2. the landscape architectural tools and their effects that can influence these meteorological processes and thus the microclimate of the area were collected: 


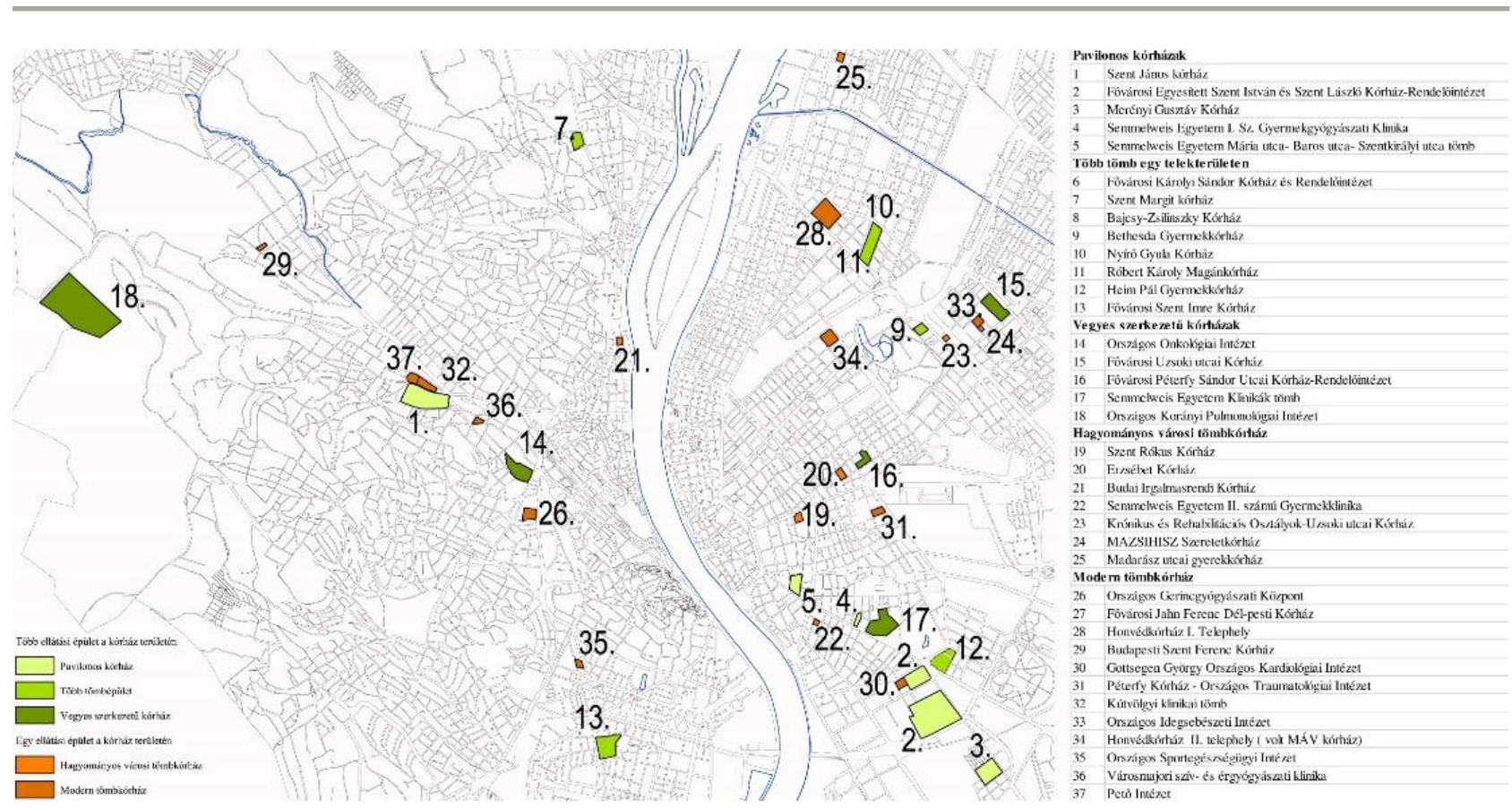

Fig. 1. Budapest hospitals (Takácsné Zajacz and Mezősné Szilágyi 2019)

Table 2. Landscape planning tools and their impact on local climate

\begin{tabular}{|c|c|c|c|}
\hline & Impact on local climate & $\begin{array}{l}\text { Possibility to } \\
\text { intervene in } \\
\text { climate } \\
\text { improvement }\end{array}$ & $\begin{array}{l}\text { Limitations, disadvantages } \\
\text { and weaknesses of the } \\
\text { intervention }\end{array}$ \\
\hline \multicolumn{4}{|l|}{ Vegetation } \\
\hline General & $\begin{array}{l}\text { leaf area index (LAI), } \\
\text { influences evaporation and heat } \\
\text { removal }\end{array}$ & $\begin{array}{l}\text { increase green } \\
\text { area index }\end{array}$ & $\begin{array}{l}\text { affect or limit the use of open } \\
\text { spaces (e.g. lack or reduction } \\
\text { of sunbathing lawns, natural } \\
\text { ball fields) }\end{array}$ \\
\hline \multirow[t]{3}{*}{ trees } & $\begin{array}{l}\text { shading, reduces sky visibility, } \\
\text { increases LAI thus promoting } \\
\text { evaporation }\end{array}$ & $\begin{array}{l}60-65 \% \text { increase } \\
\text { in canopy cover }\end{array}$ & $\begin{array}{l}\text { affect or limit the use of open } \\
\text { spaces (e.g. lack or reduction } \\
\text { of sunbathing lawns, natural } \\
\text { ball fields) }\end{array}$ \\
\hline & $\begin{array}{l}\text { small-leaved species: lower } \\
\text { canopy temperatures } \\
\text { (Leuzinger et al. 2010) }\end{array}$ & \multirow[t]{2}{*}{$\begin{array}{l}\text { mixed stock } \\
\text { development }\end{array}$} & \\
\hline & $\begin{array}{l}\text { broad-leaved species: more } \\
\text { shade, better use of rainwater } \\
\text { (Hrotkó 2013) }\end{array}$ & & \\
\hline \multirow[t]{2}{*}{ shrub } & $\begin{array}{l}\text { affects the flow of air through } \\
\text { the park's air circulation system } \\
\text { (park circulation - PC) ( Unger } \\
\text { 2010) }\end{array}$ & & may impair local flow \\
\hline & $\begin{array}{l}\text { leaf area index (LAI), } \\
\text { influencing evaporation and } \\
\text { associated heat removal }\end{array}$ & $\begin{array}{l}\text { LAI increases, } \\
\text { evaporation } \\
\text { increases }\end{array}$ & \\
\hline lawn level & $\begin{array}{l}\text { Leaf area index (LAI), } \\
\text { influencing evaporation and } \\
\text { associated heat removal }\end{array}$ & $\begin{array}{l}\text { LAI increases, } \\
\text { evaporation } \\
\text { increases }\end{array}$ & \\
\hline $\begin{array}{l}\text { roof } \\
\text { garden }\end{array}$ & $\begin{array}{l}\text { controls incoming short-wave } \\
\text { radiation, long-wave radiation }\end{array}$ & $\begin{array}{l}\text { greening of flat } \\
\text { roofs }\end{array}$ & $\begin{array}{l}\text { can only be used on flat roofs, } \\
\text { is expensive to build and }\end{array}$ \\
\hline
\end{tabular}




\begin{tabular}{|c|c|c|c|}
\hline & $\begin{array}{l}\text { from buildings, influences } \\
\text { evaporation, reduces heating of } \\
\text { the roof structure ( Gerzson and } \\
\text { Oláh 2012) }\end{array}$ & & $\begin{array}{l}\text { maintain intensively, and } \\
\text { cannot be installed on all } \\
\text { structures }\end{array}$ \\
\hline greenwall & $\begin{array}{l}\text { regulates incoming short-wave } \\
\text { radiation, long-wave radiation } \\
\text { from buildings, influences } \\
\text { evaporation, vaporization, } \\
\text { regulates wall temperature } \\
\text { (Dezsényi et al. 2016) }\end{array}$ & $\begin{array}{l}\text { designing green } \\
\text { walls }\end{array}$ & $\begin{array}{l}\text { supporting vegetation is } \\
\text { costly and maintenance- } \\
\text { intensive, and not feasible for } \\
\text { all structures, and planting } \\
\text { without supporting vegetation } \\
\text { may face physical and } \\
\text { population constraints }\end{array}$ \\
\hline \multicolumn{4}{|c|}{ Pavement (Égerházi 2014) } \\
\hline $\begin{array}{l}\text { colour and } \\
\text { material }\end{array}$ & affects long-wave radiation & increase albedo & dazzling cover in summer \\
\hline construction & $\begin{array}{l}\text { its rainwater retention capacity } \\
\text { affects surface } \\
\text { evaporation/evaporation }\end{array}$ & $\begin{array}{l}\text { permeable } \\
\text { pavement }\end{array}$ & more expensive \\
\hline volume & affects long-wave radiation & $\begin{array}{l}\text { quantitative } \\
\text { reduction }\end{array}$ & a reduction in traffic space \\
\hline \multicolumn{4}{|c|}{ Water surfaces } \\
\hline & affects the humidity of the air & $\begin{array}{l}\text { rehabilitation, } \\
\text { establishment of } \\
\text { new water surface }\end{array}$ & $\begin{array}{l}\text { has an impact on a small } \\
\text { surface area, is costly to build } \\
\text { and maintain }\end{array}$ \\
\hline \multicolumn{4}{|c|}{ Microarchitectures } \\
\hline $\begin{array}{l}\text { fences, } \\
\text { walls }\end{array}$ & $\begin{array}{l}\text { affects the airflow system in the } \\
\text { park (Oláh, 2012) }\end{array}$ & $\begin{array}{l}\text { none or less than } \\
0,5 \mathrm{~m}\end{array}$ & $\begin{array}{l}\text { cannot be demolished } \\
\text { everywhere for reasons of } \\
\text { monument protection and } \\
\text { townscape }\end{array}$ \\
\hline
\end{tabular}

\section{Materials and methods}

The aim of the research is to examine and prove how green areas and gardens created during landscape architecture participate in shaping local and microclimatic conditions, and whether they are able to influence the climatic conditions of the area. For this study, we have prepared 3-dimensional maps of the current and proposed or planned condition of the hospital gardens for better ecosystem services, and then we run climate simulations on these maps using a special program.

For this study, the microclimate modeling software ENVI-MET was used, which is able to simulate climatic conditions and their changes at a given time, under given meteorological conditions and for a given geographical situation, using 3-dimensional models. The simulation program took into account short- and long-wave radiation, shading, evaporation of plants and surfaces, dynamic surface temperature and water and heat exchange in the soil. From the data, air temperature conditions, relative humidity, wind conditions and radiation conditions were determined and analyzed at different times. A biometeorological simulation program is also linked to the simulation program, which is used to run the data obtained to determine the thermal sensation and its variation, using the Physiologically Equivalent Temperature (PET) index.

As a sample area, we have chosen two hospitals in the city centre of Budapest, which are firmly embedded in the city and have now become practically part of the city centre: 
- Szent Rókus Hospital - a classic urban hospital with two buildings, one large and one small courtyard, built in a closed structure;

- Péterfy Sándor Hospital - formerly a pavilion hospital, now a mixed structure hospital with a large block.

\section{Szent Rókus Hospital (Takácsné Zajacz 2020)}

The hospital opened in 1796 (Fig. 2a.). The 3-storey building accommodated patients from different social classes in nearly 300 beds. A small open-air reception area can be seen in the ornamental garden in the inner courtyard of the building complex, in front of the main entrance, as shown in contemporary depictions and in engravings and photographs from the turn of the century (Fig. 2b.). In the 20th century, the design and function of the garden changed, the enclosed front garden was transformed into a reception area, while the inner courtyard was extended with parking facilities at the expense of the ornamental garden (Fig. 2c.). By the 1970s, parking was added not only to the courtyard but also to the front garden.
In the 1990s, new buildings were built in the courtyard, and the ornamental garden was partially removed. (Fig. 3b.) The parking function was increased, which meant an increase in the size of the paved areas. The front garden has been redesigned over the last decade and, as in the 1830s, has been partially enclosed and closed off from the community (Fig. 3c., Fig. 3d.). The vegetation in the interior courtyard is typically single level, with only significant canopy cover and adequate canopy cover. The front yard vegetation is varied, with groundcovers and a variety of ornamental shrubs and trees.

\section{Péterffy Sándor Hospital (Takácsné Zajacz 2020)}

The first buildings of the hospital were constructed in the 1890s, with a one-storey brick pavilion design. Then, in two phases, between 1931-32 and 1940-42, a new 6-storey building was constructed, extending the full width of the garden. Several service buildings were added to the courtyard, which eliminated much of the garden between the pavilions.
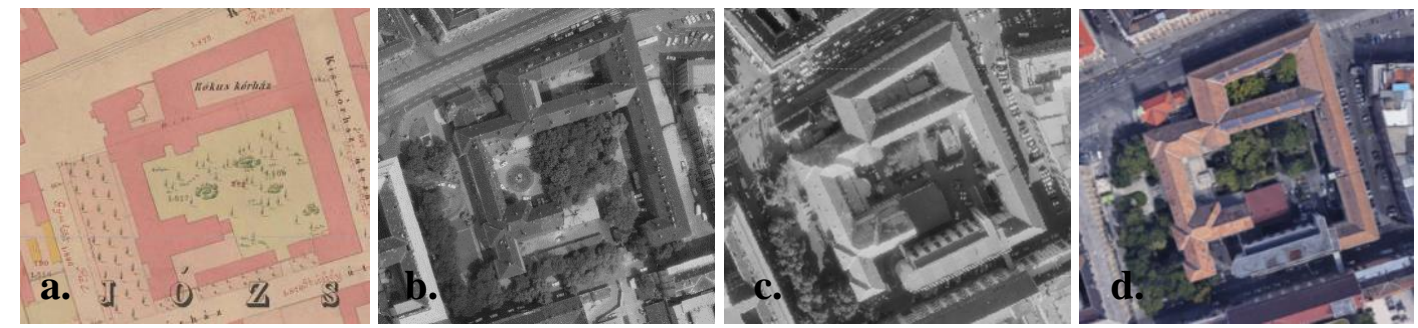

Fig. 2. Szent Rókus Hospital: a. Map from 1867-72; b. Air photo 1972; c. Air photo 1995; d. Air photo 2021
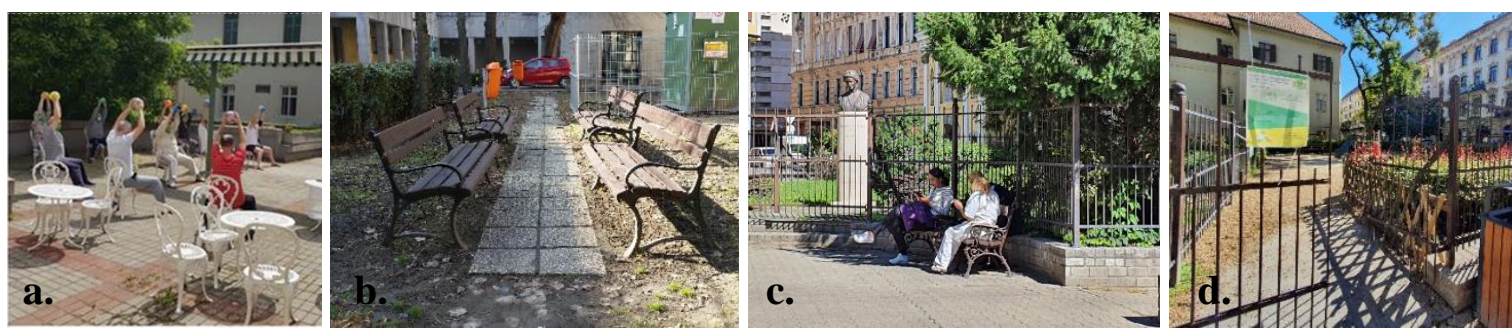

Fig. 3. Szent Rókus Hospital: a. Therapeutic gymnastics area; b. Inner courtyard; c. Front garden; d. Dog run 
The building process can be clearly followed on maps and aerial photographs.

The 1964 airphoto (Fig. 4a.) shows that there is an ornamental fountain in the courtyard, which is preserved in a photo documentation, but now only the basin of the fountain is visible (Fig. 5b.). In the early 2000s, the demolition of the service buildings did not increase the green area, but the area of the car parks. After the demolitions of 20062007, a recreation garden was created. In 2009 a new complex of buildings with underground parking was added to the courtyard, but unfortunately, this did not eliminate parking surfaces. Moreover the parallel (Fig. 4c.) parking along the edge of the ornamental garden was replaced by perpendicular parking (Fig. 4d.), while parking between the pavilions was replaced by parking with crushed stone paving, further reducing the green area. (Fig. 5c.).

The whole garden is characterized by the fact that there is practically no shrub cover in the extensively managed, weedy lawns. However, the canopy cover is good, but the stand is partly old and neglected, and partly composed of invasive species along the margins.
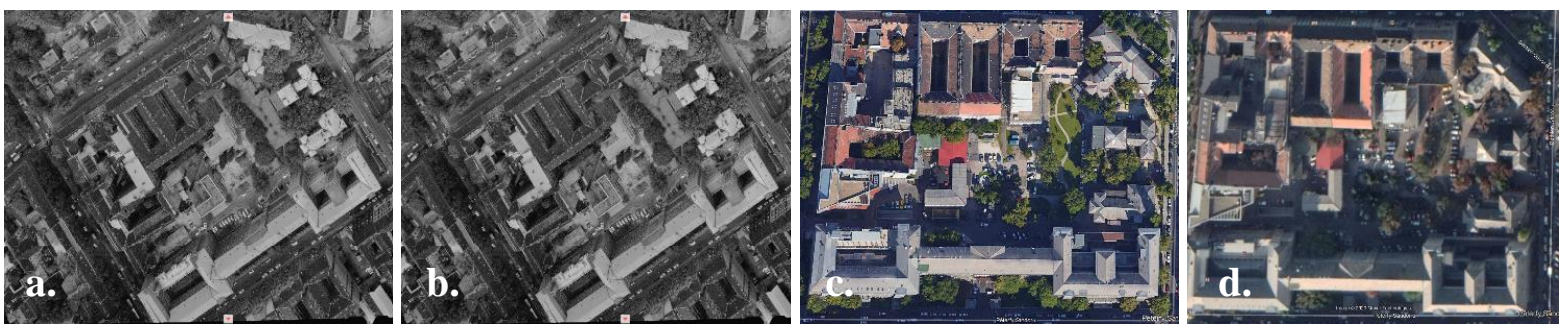

Fig. 4. Péterffy Sándor Hospital: a. Airphoto1964; b. Airphoto1972; c Air photo 2016; d. Air photo 2017
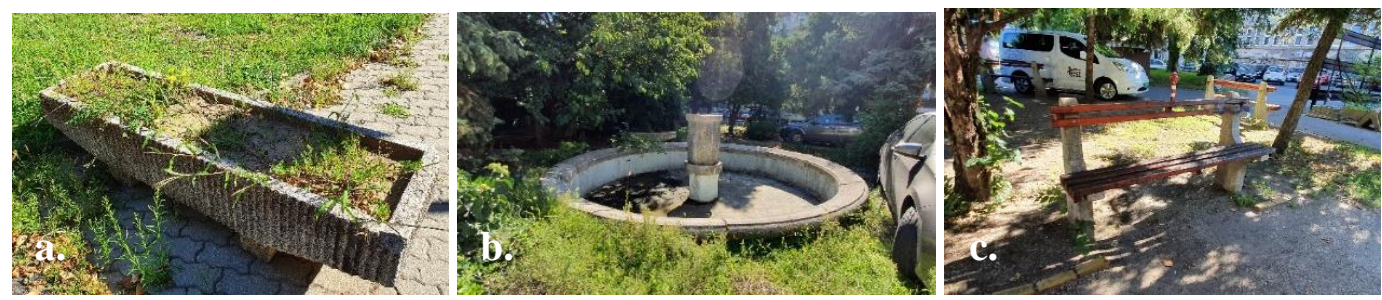

Fig. 5. Péterffy Sándor Hospital: a. Plant container; b. empty fountain no longer in use;

c. bench and paving

\section{Simulation / Study}

In the case of Rókus Hospital, the climatic impact of the ratio and intensity of green areas was modeled. In the conceptual design state, the effects of increasing the canopy cover, changing the type and amount of pavement, and creating an extensive roof garden were simulated using indicators of local climate and thermal comfort. The conditioning effect of the water surface and the fountain in the case of Péterfy Sándor Hospital was investigated, as there are no such conditions in the area of the Rókus Hospital.

In ENVI-MET, the simulation was performed with the geographic data of the hospitals and with general meteorological conditions (22-34 ${ }^{\circ} \mathrm{C}$, winds from NW 2.5 $\mathrm{km} / \mathrm{h}$ ) on August 1st. For both hospitals, heat maps and sections were analysed at 5 time points (8:00, 12:00, 13:00, 16:00, 20:00).

The simulation was also run for the original and the theoretical planned hypothetical state of the hospitals. Models 
representing the 3-dimensional initial state were created from the air photo and plotted in a $2 \times 2 \mathrm{~m}$ raster. The planned 3-dimensional model was carried out by enhancing the original building and space configuration in such a way that the changes to the landscape architecture in the hospital garden, as summarized in Table 2., would have the most positive impact on the microclimate of the garden.

The following changes were made to the conceptual proposal (Fig 6b., Table 3.):

The front garden and the hospital surroundings:
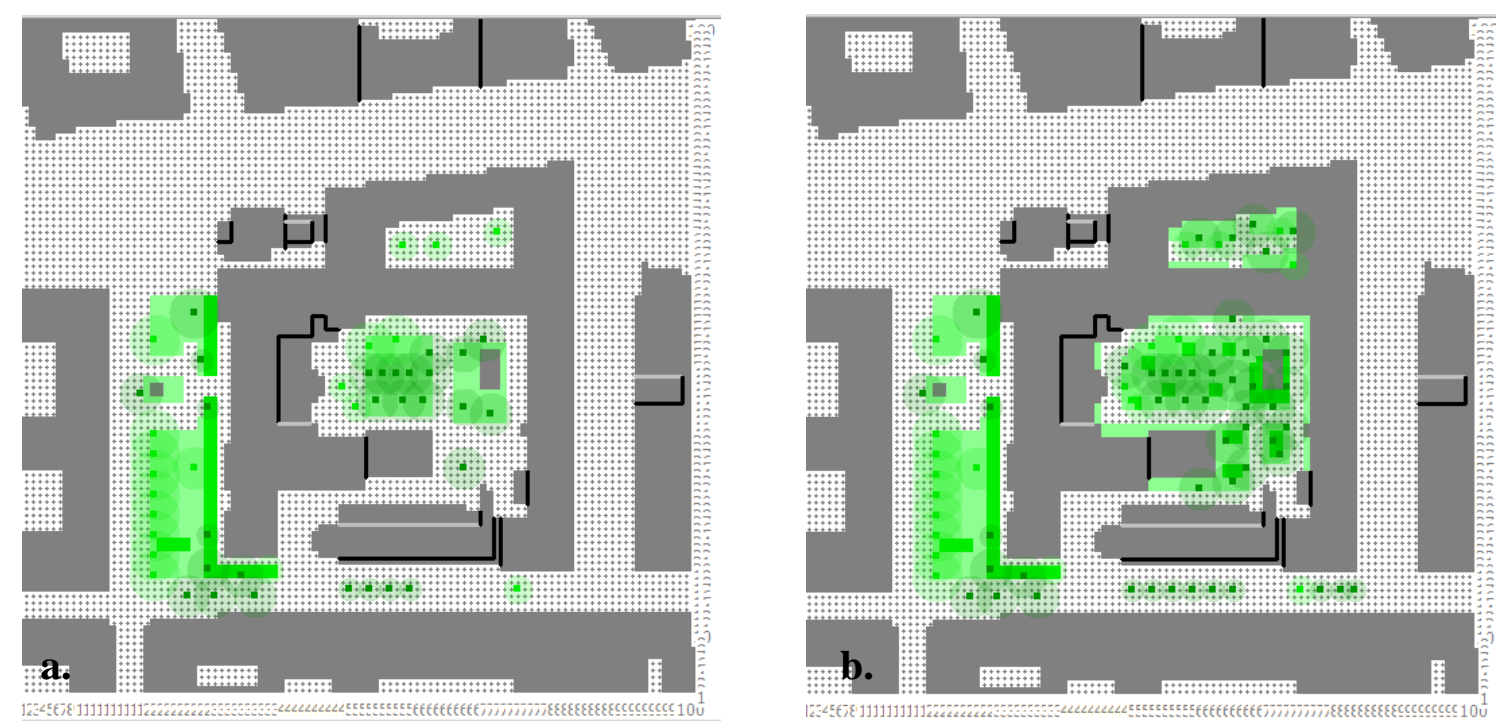

Fig. 6. a. Original and b. planned model map of green surfaces and canopy cover

Table 3. The data of the models

\begin{tabular}{|l|c|c|c|c|}
\hline & $\begin{array}{l}\text { original } \\
\text { whole area }\end{array}$ & $\begin{array}{l}\text { original area } \\
\text { Internal } \\
\text { courtyards }\end{array}$ & $\begin{array}{l}\text { planned } \\
\text { whole area }\end{array}$ & $\begin{array}{l}\text { planned area } \\
\text { Internal } \\
\text { courtyards }\end{array}$ \\
\hline buildings & $54 \%$ & & $54 \%$ & \\
\hline $\begin{array}{l}\text { paved } \\
\text { surfaces }\end{array}$ & $29 \%$ & $75 \%$ & $21 \%$ & $48 \%$ \\
\hline green space & $17 \%$ & $23 \%$ & $25 \%$ & $50 \%$ \\
\hline canopy cover & $17.5 \%$ & $35 \%$ & $30 \%$ & $68 \%$ \\
\hline
\end{tabular}

The air temperature and thermal environment (PET) maps of the resulting models were analyzed and compared at the respective time points between the planned and

- Pavement reconstruction with a higher albedo material (asphalt $(0,12)$-concrete $(0,48))$ on the sidewalk around the building and in the forecourt

- Completion of the missing urban street trees

Internal courtyards:

- Increasing the green space index

- Create continuous green space

- Increase canopy cover

- Extensive roof garden

- Pavement reconstruction with a higher albedo (asphalt $(0,12)$-concrete $(0,48))$ 
microclimate control role are clearly visible. We also analyzed the temperature and thermal variations plotted on the sections.

The differences between the heat maps and temperature maps allowed us to draw conclusions about the applicability and usefulness of general design principles, and the sections highlighted design guidelines for the use of specific landscape architectural tools.

\section{Results and discussion}

\section{Study of the Rókus Hospital}

The heat map plotted at five different points in time shows that the reduction of paved surfaces, the increase in green areas, the consolidation of green areas and the increase in cover reduce the air temperature in the area by 1 to $1.5^{\circ} \mathrm{C}$ (Fig. 7.).
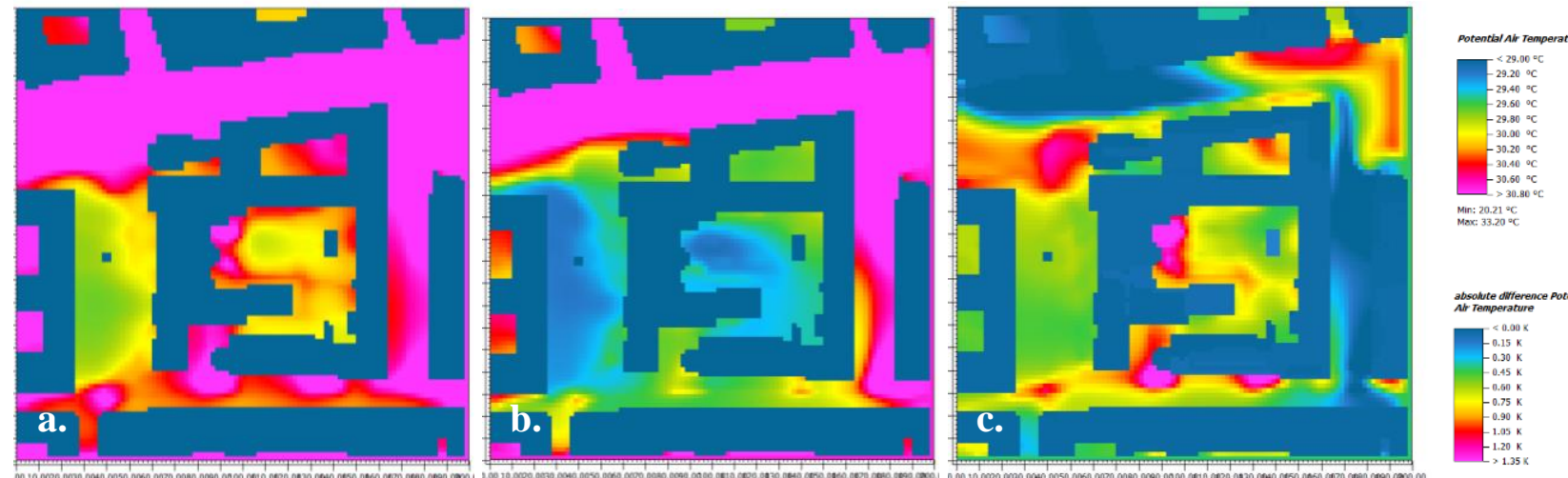

Fig. 7. a. Air temperature in the original and b. planned open space system; c. air temperature differences of original and planned situation

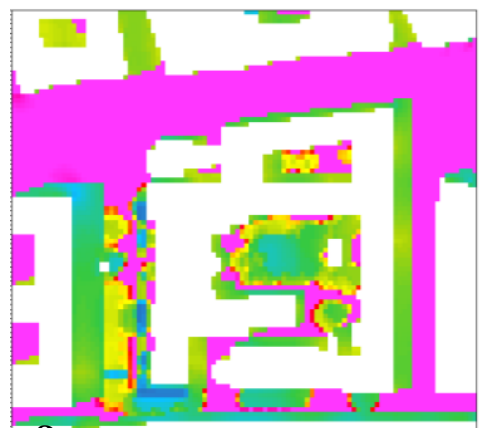

a.
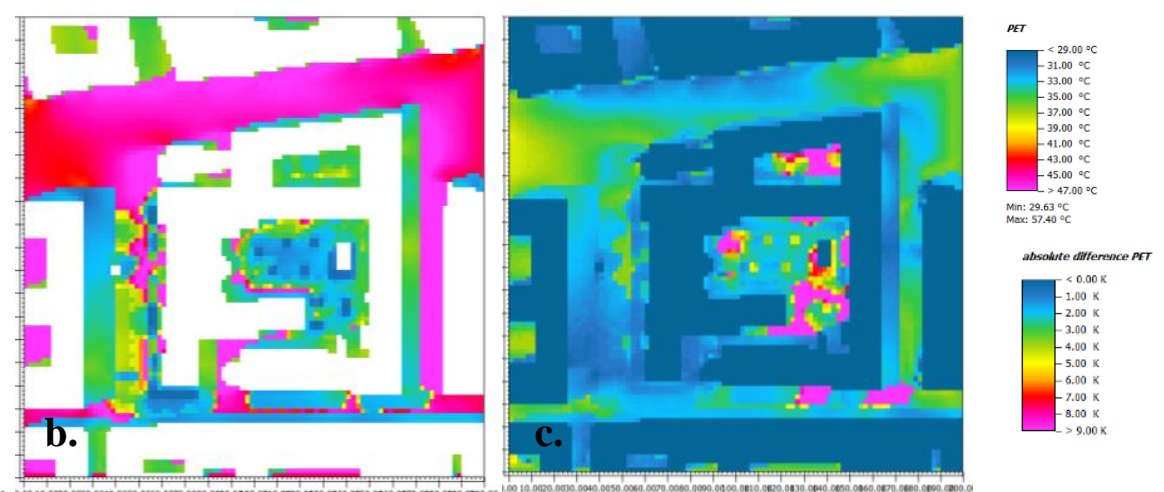

Fig. 8. a. PET in the original and b. planned open space system; c. PET differences of original and planned situation

Table 4. The temperature differences

\begin{tabular}{|c|c|c|}
\hline & Air Temperature Difference & PET Difference \\
\hline $\mathbf{8 : 0 0}$ & $0.8^{\circ} \mathrm{C}$ & $22.01{ }^{\circ} \mathrm{C}$ \\
\hline $\mathbf{1 2 : 0 0}$ & $0.44^{\circ} \mathrm{C}$ & $20.88{ }^{\circ} \mathrm{C}$ \\
\hline $\mathbf{1 3 : 0 0}$ & $1.89^{\circ} \mathrm{C}$ & $23.20{ }^{\circ} \mathrm{C}$ \\
\hline $\mathbf{1 6 : 0 0}$ & $1.05^{\circ} \mathrm{C}$ & $21.20^{\circ} \mathrm{C}$ \\
\hline $\mathbf{2 0 : 0 0}$ & $0.81{ }^{\circ} \mathrm{C}$ & $1.71{ }^{\circ} \mathrm{C}$ \\
\hline
\end{tabular}


Other factors affecting the thermal comfort, such as air movement, radiation conditions and changes in relative humidity due to evaporation, had a much stronger influence on the PET value (Fig. 8.).

The temperature change in the area can reach $20-23{ }^{\circ} \mathrm{C}$, depending on the time of day and the sub-area.

The changes are defined as the difference between the temperature at a given time, at a given unit area, simulated for the original state of the garden and the temperature simulated for the planned state of the garden. In all cases, this is a decrease and therefore a positive value for the result.

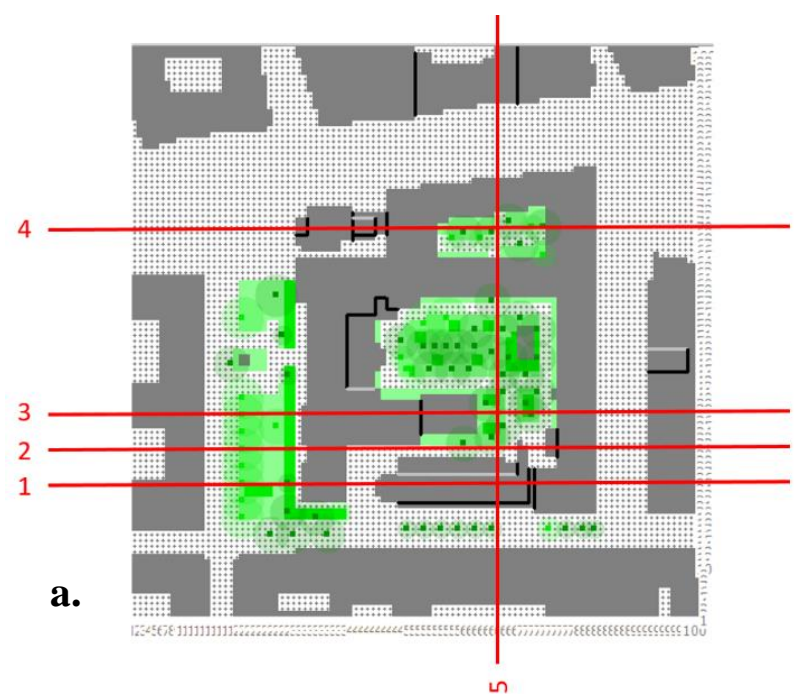

The largest changes in temperature and thermal sensation were observed around 1 p.m. during the hottest hours. The smallest change is measured in the evening hours; this is presumably due to the relatively large shading of the buildings, which has a significant effect on the thermal sensation (Table 4.) (Gulyás, 2009).

The effects of different landscape interventions can be illustrated by crosssectional diagrams. Five cross-sectional heat maps, defined by the distribution of green areas, show the changes in temperature and thermal comfort conditions and the changes in temperature and thermal comfort (Fig. 9.).

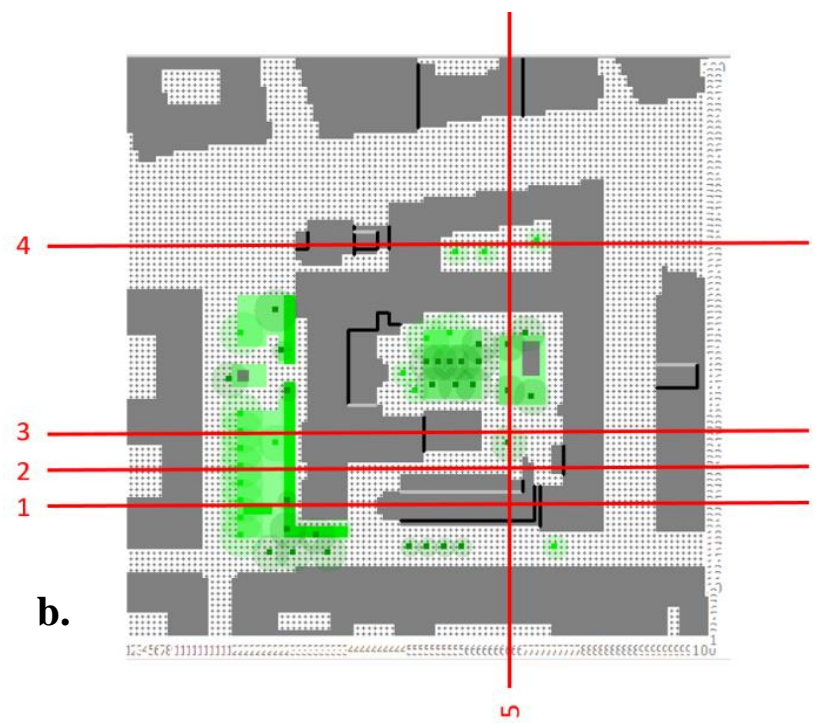

Fig. 9. a. Original and b. planned model maps with cross sections

We examined cases where only the quality and albedo of the pavement changed (section 1, 2 ), where new green space and extensive roof gardens were created (section 3,4), and where the density of trees increased but no new canopy cover was established (section 5). Of course, other data can be read from these transects, such as the main role of trees in the horizontal shading of the building and its climate and thermal modification effects, and up to up the heights this effect reaches.
During the analysis of the cross-sections the following was found:

- with the change of the albedo of the paved surfaces, the air temperature decreased by about $0.5-1{ }^{\circ} \mathrm{C}$, and the thermal comfort decreased by only 1 $2^{\circ} \mathrm{C}$

- the extensive green roof did not meet expectations, with no significant change in either air temperature or thermal comfort $\left(0.5-1^{\circ} \mathrm{C}\right)$ 
- the replacement of the cover with a grass surface did not result in significant changes in temperature and thermal comfort either $\left(0.5-1{ }^{\circ} \mathrm{C}\right)$

- where the pavement was replaced by 23 levels of vegetation, i.e. canopy cover and thus higher green cover intensity, a larger temperature difference $\left(1-1.5^{\circ} \mathrm{C}\right)$ and even more significant temperature difference (up to $20-23{ }^{\circ} \mathrm{C}$ ) was observed

\section{AIR TEMPERATURE DIFFERENCE}

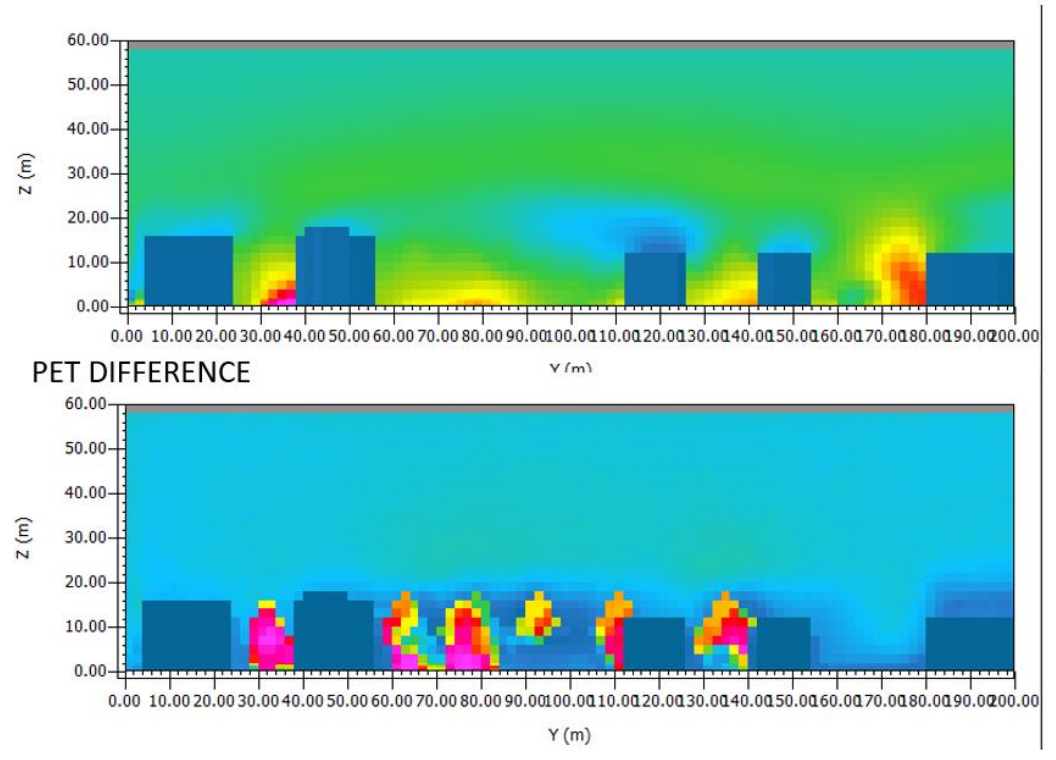

Fig. 10. Section 5
- there is practically no change in temperature and thermal comfort by thickening the canopy cover of the existing stand

- the shading and climate modification effect of the canopy close to the building is also felt at higher levels of the building, with a reduction of up to $20{ }^{\circ} \mathrm{C}$ in thermal comfort

\section{Péterfy Sándor Hospital}

Models and simulations of the garden of Péterfy Sándor Hospital were also prepared for the study of the original and planned condition at the respective dates. Similar results were obtained for the two hospital gardens. The fountain in the garden of the Péterfy Street Hospital, which unfortunately is no longer functioning, provided a good opportunity to model the impact of the water surface. We "reconstructed" the fountain in the theoretical model design and examined the climate modifying effect of the moving water. Here, too, we analyzed both (potential air temperature, PET) heat maps, and a two-way cross-sections. The relative humidity modifying effect of a working fountain has been shown to have a very large climate modifying effect, both horizontally and vertically; the moving water mass can reduce potential air temperature by up to $5.5^{\circ} \mathrm{C}$ (Fig. 11., 12.). However, the change in humidity does not cause such an extra change in thermal comfort; here, as in well-shaded areas, the temperature drop is around $22^{\circ} \mathrm{C}$.

The climatic modification effect of the water surface depends to a large extent on the air movement, both vertically and horizontally, as the plume on the horizontal heat map shows the prevailing wind direction from the NW. 


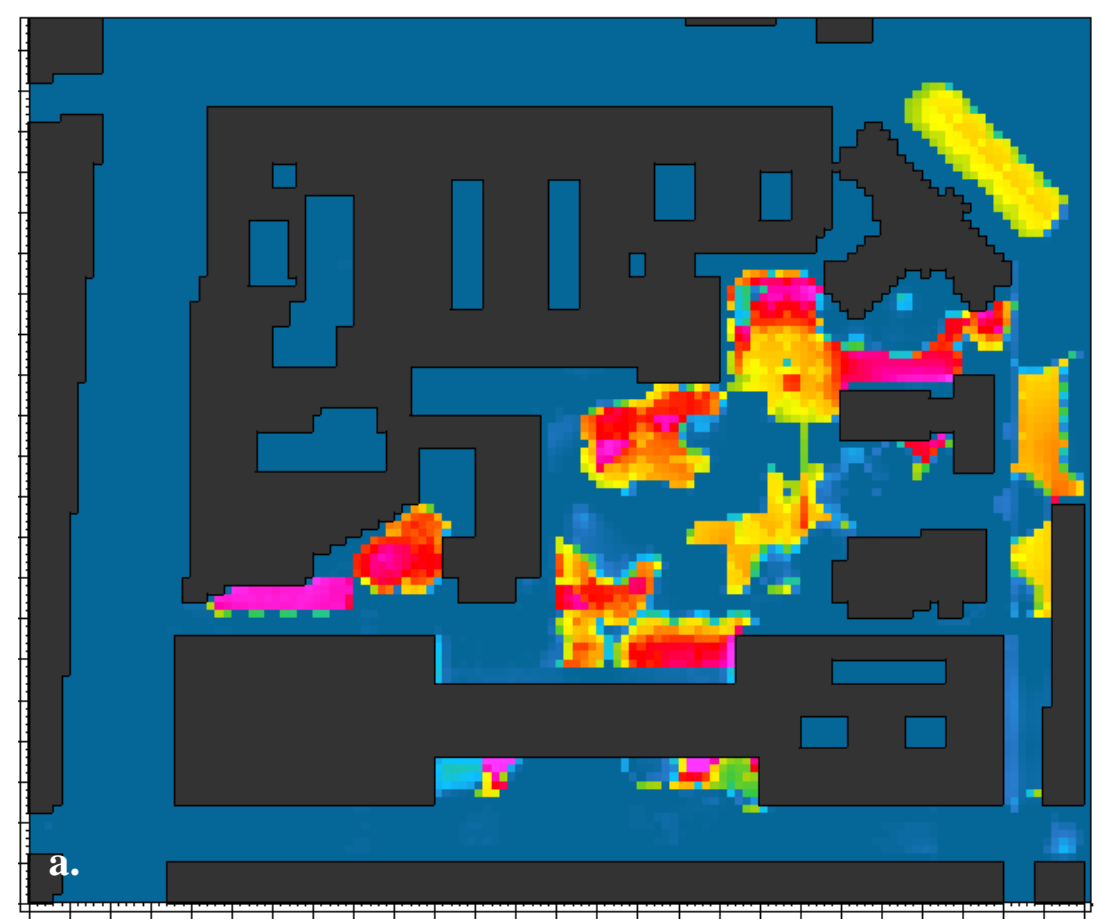

$13.00 . \overline{00} 01.08 \overline{2020}$ 、 Peterfy_terv_04_15 13 . ( 01.08 .2020

$\mathrm{x} / \mathrm{y}$ Cut at $k=2(z=1.0000 \mathrm{~m})$

absolute difference PET

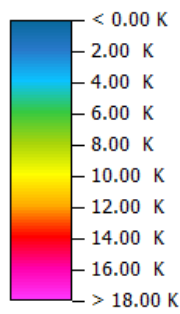

Min: $-14.40 \mathrm{~K}$

Max: $21.80 \mathrm{~K}$

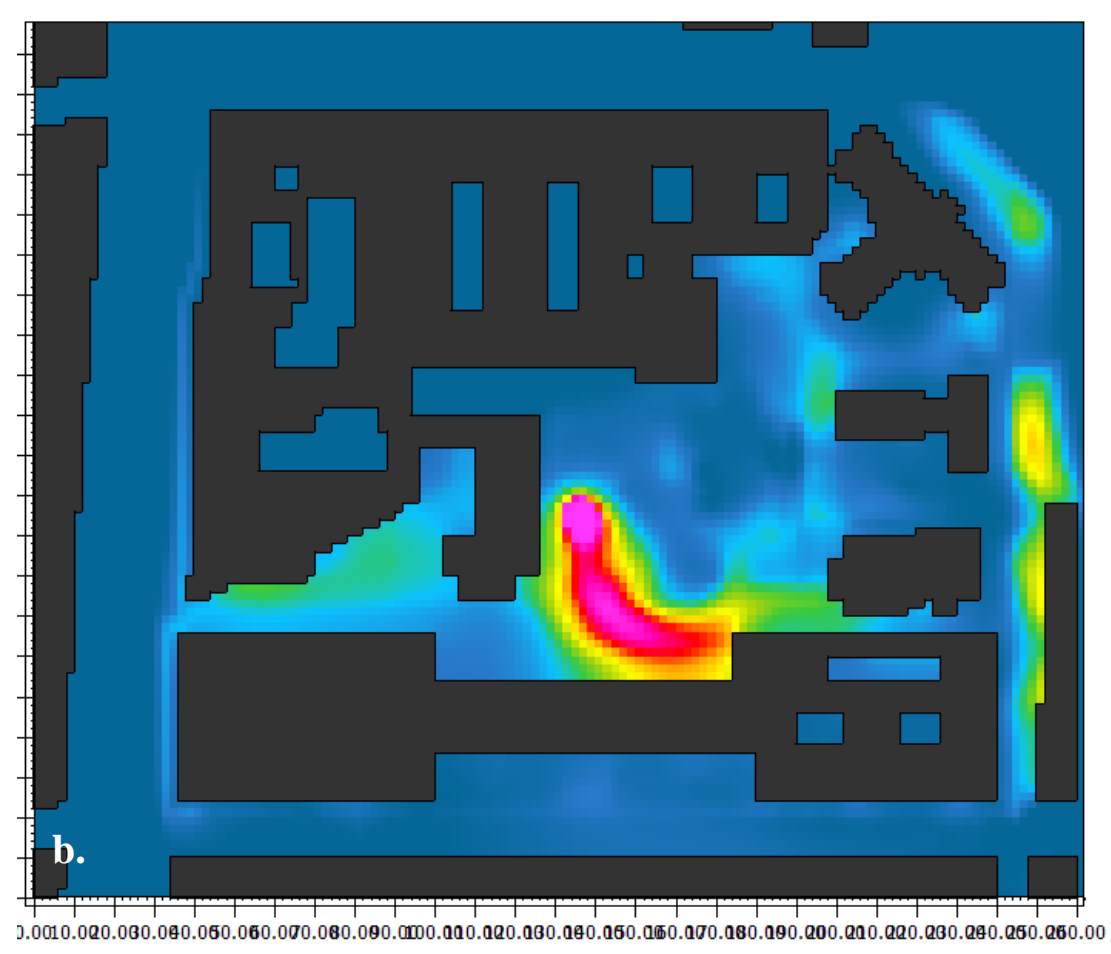

13.00.00 01.08. $\overline{20} \overline{20}$ Peterfy terv 04_15 13 01.08 .2020

$x / y$ Cut at $k=2(z=1.0000$

absolute difference Air temperature

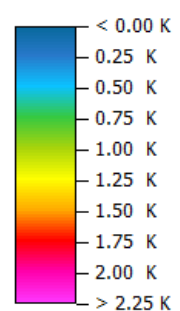

Min: $-1.03 \mathrm{~K}$ Max: $5.52 \mathrm{~K}$

Fig. 11. a. PET in the original and planned open space system; b. PET differences of original and planned situation 
a.
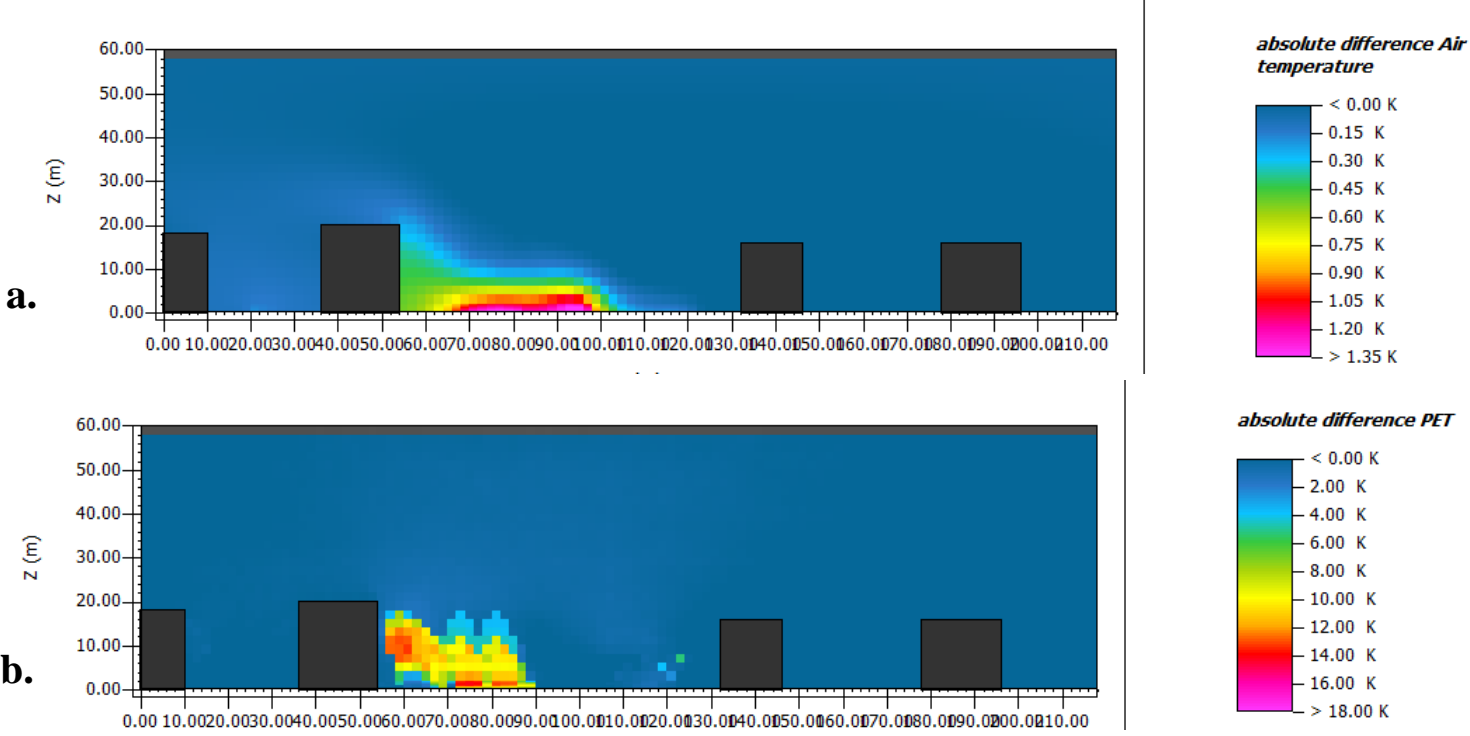

Fig. 12. a. Original, b. planned air temperature differences section and PET differences section

\section{Conclusions}

The simulations have shown that landscape architecture can have a significant influence on the micro- or local-climatic conditions of hospital gardens.

However, the $2 \times 2 \mathrm{~m}$ scale of the used model does not provide an answer to the effectiveness of all landscape architectural tools in influencing the microclimate in how and how they affect it, so it was not possible to simulate the effect of fences, retaining walls and other micro architectural features, nor to isolate the effect of individual tree species with different leaf area indices and evaporative capacities.

However, the effects of changes in green area, cover and canopy cover, the choice of paving types and the appearance of water surfaces on the climatic conditions of the area were clearly observed. However, the extensive roof garden did not cause significant changes, so its role in the local climate is debatable. Although the building has a thermal insulating effect in terms of energy, its value for the ecology of the settlement is questioned. This raises the question of reconsidering the inclusion of the proportion of extensive green roofs in the green space index. Further research should also examine the impact of more intensively planted and maintained green roofs.

Further studies should be carried out to clarify the issues raised, and the ENVI-MET program could be used for this purpose, as it is capable of simulating climatic conditions in a grid of up to $0.5 \mathrm{~m} \times 0.5 \mathrm{~m}$. This allows for more detailed studies, even of selected subareas, to map the role of certain plants and micro architectures in the microclimate.

\section{Acknowledgement}

I would like to thank my supervisor, Prof. Kinga Szilágyi for her immense patience, lots of useful advice, ideas and help, which made my participation in the conference possible.

Supported by the ÚNKP-2020-3-II New National Excellence Program of the Ministry for Innovation and Technology from the source of the National Research, Development and Innovation Fund.

\section{Conflict of interest}

The authors declare no conflict of interest. 


\section{References}

1. Dezsényi P, Pataky R, Csibi K, et al (2016) ZÖLDHOMLOKZATOK Függőleges zöldfelületek tervezésének, kivitelezésének müszaki és kertészeti útmutatója, Budapest Főváros Városépítési Tervező Kft. Budapest

2. Gerzson L, Oláh A (2012) A zöld építészet tájépítészeti vonatkozásai, eszközrendszere. 4D Tájépítészeti és Kertmüvészeti folyóirat

3. Gulyás Á (2009) Humán bioklimatológiai értékelések különböző léptékü megközelítésben, 2009th edn. SZTE TTIK Éghajlattani és Tájföldrajzi Tanszék, Szeged

4. Hrotkó K (2013) Városi fák környezeti hasznának vizsgálata.

https://docplayer.hu/43293800-Varosi-fakkornyezeti-hasznanak-vizsgalata-dr-hrotkokaroly.html

5. Oláh A (2012) A Városi beépítettség és a felszíntípusok hatása a kisugárzási hőmérsékletre. Budapesti Corvinus Egyetem, Tájépítészeti Kar, Kert- és Szabadtervezési Tanszék, Budapest

6. Páldy A (2018) Magyar Tudomány 2018/9 - A klímaváltozás hatása egészségünkre és az egészségügyre Magyarországon MeRSZ.

https://mersz.hu/dokumentum/matud_307. Accessed 7 Jun 2021

7. Unger J (2010) A városi hősziget-jelenség néhány aspektusa. Szeged
8. Égerházi LA (2014) Városi közterületek komplex humán-bioklimatológiai értékelése és annak várostervezési vonatkozásai szegedi példák alapján. http://doktori.bibl.uszeged.hu/id/eprint/2223/. Accessed 11 Mar 2021

9. Leuzinger S, Vogt R, Körner C (2010) Tree surface temperature in an urban environment. Agricultural and Forest Meteorology. https://doi.org/10.1016/j.agrformet.2009.08 .006

10. Oke TR, Mills G, Christen A, Voogt JA (2017) Urban Climates. Cambridge University Press

11. Takácsné Zajacz V (2020) A kórházkertek funkcióváltozásának elemezése budapesti kórházkertek példáján. Ifjú Tehetségek Találkozója 3808-401

12. Takácsné Zajacz V, Mezősné Szilágyi K (2019) Kórházkertek ökoszisztéma szolgáltatatása - különös tekintettel a településökológiai és zöldhálózati adottságok javítására. Tájak müködése és arculata, 349-353. 